\title{
ECOSYSTEM FOR SUCCESSFUL AGRICULTURE. COLLABORATIVE APPROACH AS A DRIVER FOR AGRICULTURAL DEVELOPMENT
}

Nino Adamashvili, Mariantonietta Fiore, Francesco Contò, Piermichele La Sala ${ }^{1}$

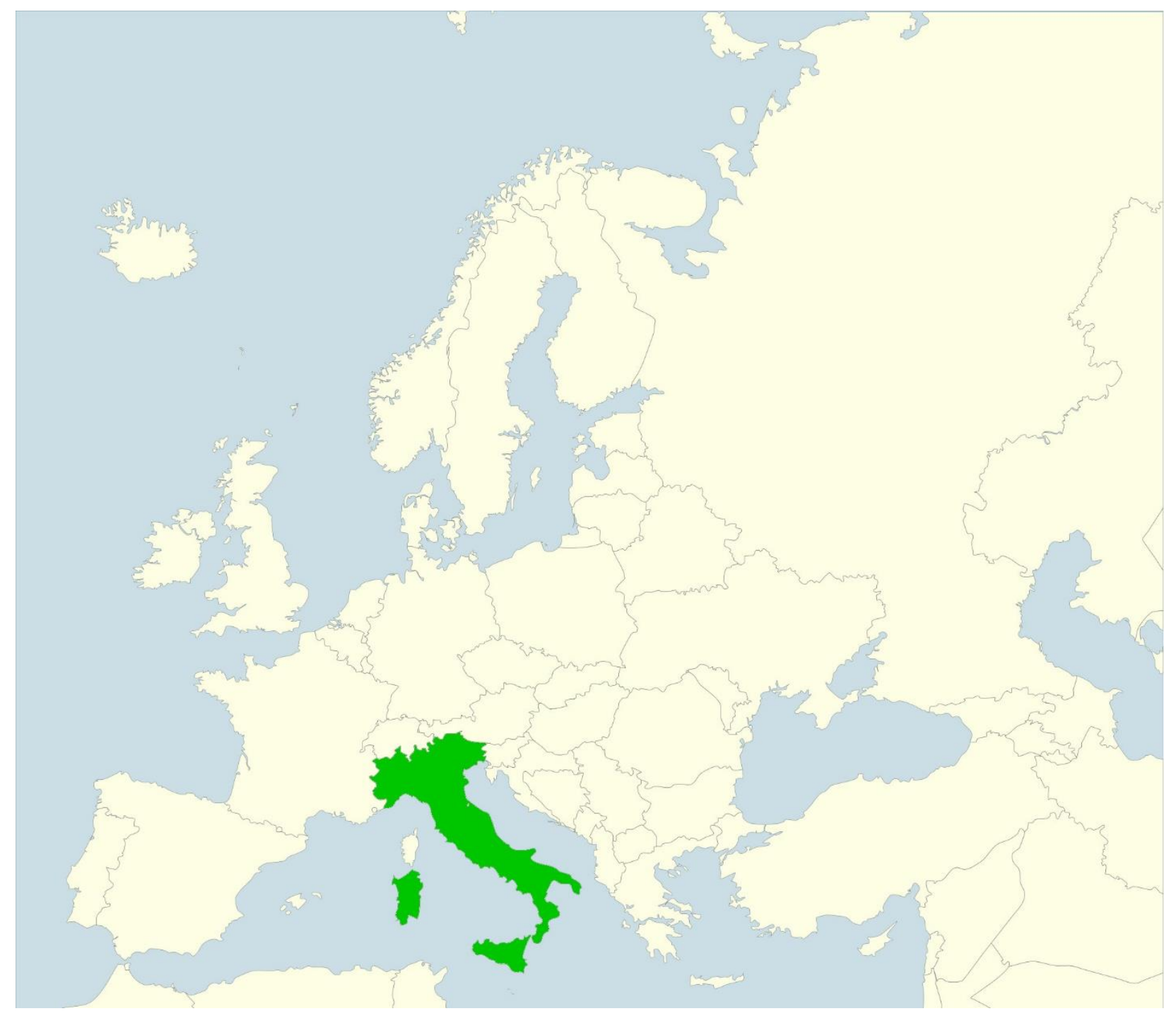

1 Nino Adamashvili, PhD. student, nino.adamashvili@unifg.it, ORCID: 0000-0001-6907-8293; Ass. Prof. Mariantonietta Fiore, PhD., mariantonietta.fiore@unifg.it, ORCID: 0000-0002-9244-6776; Prof. Francesco Contò, francesco.conto@unifg.it, ORCID: 0000-0001-7837-0069; Ass. Prof. Piermichele La Sala, piermichele.lasala@unifg.it, ORCID: 0000-0003-2081-8013. University of Foggia, Italy 
Abstract: The development of agribusiness sector is given gradually increasing importance. This works aims at identifying the elements that create the successful ecosystem for agricultural development, their benefits and application in agri-food systems; additionally, to bring on a light of the role of agricultural policies in these processes. For this purpose, the authors have carried out an analysis of the concern related literature and present a preliminary theoretical framework/model as a tool for supporting local development and incorporate a successful effective ecosystem. The key implications of this paper include an increased attention to agricultural research, to the role of the collaboration between relevant stakeholders, as well as of the agriculture, which uses information technologies for the better utilization of natural resources, and what is the most important is, the role of agricultural policies.

\section{Keywords: ICT, Sustainable Agriculture, Collaboration, CAP}

\section{Introduction}

The current world is witnessing a huge change resulting from continuously growing number of populations, resources depletion, environmental and climate changes. The world population is expected to surpass the 9.8 billion mark by 2050 (UN DESA, 2017), and agriculture has to increase the production of nutritious food to meet the growing demand and ensure food security for all (FAO, 2017). It also has to create new working opportunities, increase incomes, reduce poverty and lead rural economic growth. These are crucially important for the sustainable management of natural resources (Rapsomanikis, 2017). Therefore, farmers need to consider the value of natural resources and biodiversity and make the well-informed decisions while producing the food (European Union, 2012). Environmentally sustainable agriculture, which minimizes off-site environmental effects by using natural resources prudently, is crucial for our quality of life as now and for the future (Keeney, 1990).

It is becoming crucial in today's agricultural setting, that the gradual increase in the importance of information in agricultural activities is paid attention to (Miller et al., 2018). Besides, millions of smallholder farmers all around the world deal with certain limitations on a general basis. Precisely, difficulties such as challenging entrance barrier on the market or poor access to financial services. Furthermore, some of the other barriers include unqualified human capital resulting from low level of education and training, agricultural research, related data, and problematic physical capital as well (FAO, 2018). Nevertheless, the climate has a big impact on agricultural activities and the ignorance of weather conditions may result in many difficulties related to farms (Tenzin et al., 2017). There is also a gap between supply and demand in a long and short-term period of time. Meaning, farmers are not able to change the standard activities immediately, which correspond to the changes in consumer preferences (Teng, et al., 2010). So, nowadays farmers need to make more and more complex decisions about the land use, what to produce and in which manner, how to choose suppliers, and how to segment consumers (Rossi et al., 2012), how to reduce the risk of bankruptcy and at the same time maintain their livelihoods well and care about the society (Krantz, 2001).

Consequently, the aim of this work is to identify the elements creating the successful ecosystem for agricultural development, their benefits and application in agri-food systems; additionally, to bring on a light of the role of agricultural policies in these processes.

The following chapters of the paper are structured as follows: the next part includes the analysis of academic literature about the role of collaboration for making more sustainable agri-food and rural areas. Further, the benefits of the information technologies in agriculture are investigated. As for the third part of the article, the work presents a hypothesis of a model to provide the scheme of effective ecosystem. Finally, results and discussions, followed by the conclusion section complete the paper. 


\section{Literature review}

\subsection{The role of collaboration for sustainable agri-food and local areas}

Agri-food and rural areas are facing different idiosyncratic and covariate shocks that lead to deep crisis. Therefore, similarly to many other sectors, the focus has moved from the individual activities of firms to the networks of collaboration (Kühne et al., 2015). Agriculture sector needs to blend intensive, specialized production systems to traditional one while trying to reach a competitive advantage in a global marketplace and decreasing environmental impacts.

The changes taking place in the agri-food system require the development of partnerships increasingly oriented to the consolidation and growth of internal and external supply chains and territorial relations. There are many forms of integration that involve, at different levels, the stakeholders of the agri-food system aiming at strenghtening partnership and increasing the contractual force and the market power of the stakeholders (Cantarelli, 2016; Alho, 2015).

Therefore, the actors' networks, rural and agro-food districts, and cooperatives conducting economic and social interactions, represent key forces to promote green and innovative local development in rural areas, thus reducing the informative gap (Barati et al., 2017; Contò et al., 2016). Indeed, according to Carrillo et al. (2014), strengthening the knowledge of economy through stimulating entrepreneurship and enabling social dialogue gets increasing importance. In addition, nested markets create more and more strong strategies for local development processes and policies, by creating new chances for families' livelihood in rural areas (Schneider et al., 2016). Bojar and Drelichowski (2008) showed networking organizations of the agri-food SME in Spain, Greece, Bulgaria, Czech Republic, Lithuania and Poland that experience competition and cooperation approach, help to meet needs of consumers for safe and healthy food.

Kotu et al. (2017) demonstrated good rural infrastructure, rural road networks, and multiple information/knowledge sharing can boost adoption of sustainable intensification practices (SIPs), thus increasing the income of farmers. Therefore, the instruments of territorial and transnational integration assume great importance in the CAP. Among these instruments, the Local Action Groups (LAGs) represent the main form of territorial integration supported by the CAP in order to enhance rural areas and encourage instruments of territorial and transnational cooperation between farms and other rural development actors (Chmieliński et al., 2018). The core seems to be also acquirement of better acknowledge in policy-making initiatives and opportunities (Huttunen, 2012). Many of these initiatives are encouraged by public policies and aimed at taking full advantage of the measures, the remainders try to meet specific requirements of territory and sector. In Italy, finally, following the law of orientation for the agricultural sector, the Agri-food Districts of Quality and Rural Districts have spread, aimed at improving the territorial governance processes for the development of farms, supply chains and rural areas, in particular areas with a strong vocation and agricultural production specialization (Contò et al., 2012; Zecca et al., 2014).

Furthermore, by investigating the EU project 'CAPIRE: Assessing the multiple Impacts of the Common Agricultural Policies on Rural Economies', Viaggi et al. (2011) highlighted the crucial role played by the Local Participatory Networks (LPN) in reaching good results in sustainable and economic development of rural economies. On the other hand, the agriculture that adopts latest technologies gives a major power to farmers since Smart grid technologies can be useful tools for increasing the sustainable energy supply from agricultural residue and waste, and for delivering benefits of agricultural systems of input (Odara et al., 2015).

Furthermore, several scholars (Fischer, 2013; Casieri et al., 2010; Simatupang \& Sridharan, 2002) highlight social capital is a crucial factor for starting and maintaining economic development in poor rural areas. Moreover, close cooperation, agro-food agreements, collaborative relationships between public or private players, researchers and business-people help actors of rural systems to match demand and supply in an effective way and they are functional to perform activities with greeter results than when acting in isolation (Simatupang \& Sridharan, 2002). 
Adopting participatory multi-actor approach, involving consumers and knowledge exchange are perceived by stakeholder as the most relevant in order to enable a shift towards more sustainable systems and chains (Sacchi et al., 2018).

The following figure assumes that the level of trust between buyers and suppliers (and vice versa) is determined by three interrelated factors: (1) the effective communication and adequate sharing; (2) the existence of positive past cooperation activities and (3) the existence of private and personal bonds that seems to be important when dealing with farmers. Above all, it appears significant to adopt vertical supply or value chain integration from farmers, food processors and grocery retailers in a durable way functional to develop and maintain sustainable relationships in rural areas (Fisher, 2013).

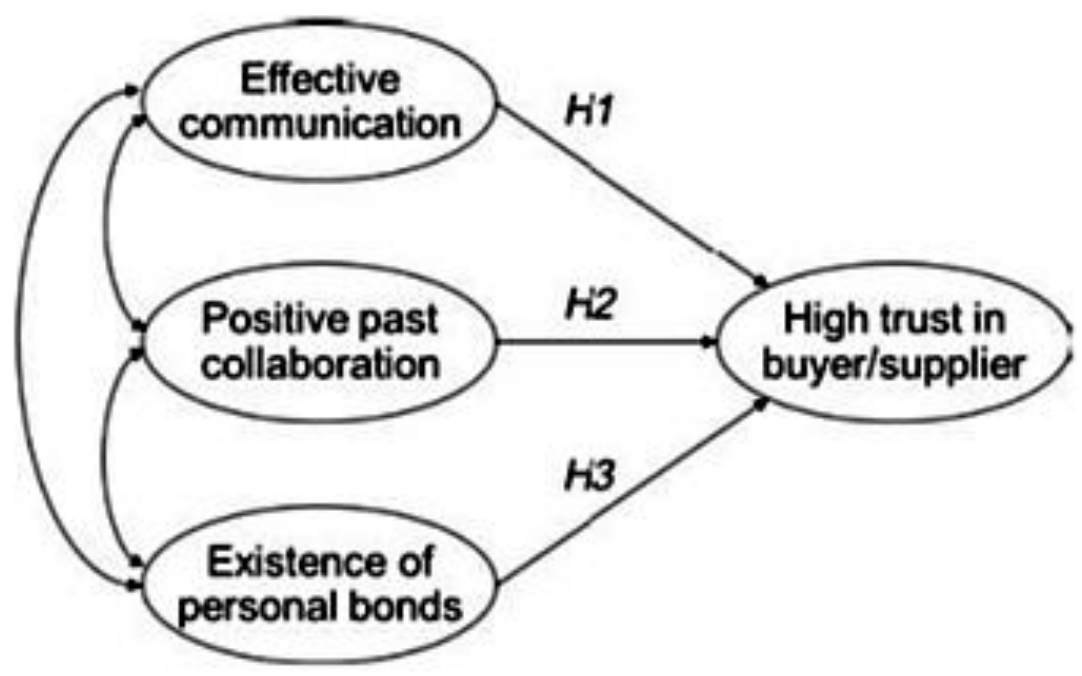

Fig 1. Assumed relationships among trust-affecting factors. Source: Fischer, 2013

Trust-based collaborations are promoted by Local Development Plans (LDPs) in order to build virtuous and continuous development mechanisms. Both Horizon 2020 framework and Common Agricultural Policy 2014-2020 stress the role of innovations: new Rural Development policies define new network tools as the European Innovation Partnership (EIP), the Operational Groups (OGs), and technological clusters designed for encouraging innovation processes (Nazzaro \& Marotta 2016).

Integrated environmental research and networking of the agricultural economy in rural areas is a trend that already started for two decades ago when processes began to move towards the disappearance of the old rural organisation (Luostarinen, 1998).

Currently, in various French and Brittany regions, rural networks of farmers organise exchange groups to help newcomers and facilitate knowledge exchange on new tools and practices. The EU TRADEIT project (www.tradeitnetwork.eu) was born as a collaboration among researchers, food networks, traditional SMEs, clusters, technology providers, food associations and entrepreneurial networks with the aim to promote, smart use of IT for traditional food producers, relationship building, sustainable technology for food production and so on (EIP AGRI, 2015). Besides, Weaver (2008) argues that increasing use of innovative technologies has opened new opportunities on the one hand, yet it has resulted in the need of strategic reorientation that should be supported by collaborative activities in the supply chain.

Finally, the manner to accomplish this approach can be built going through the currently fragmented marketplace based on power and competition via research and trust-based networks towards an integrated, consistent and entirely sustainable supply system (Fisher, 2013). 


\subsection{The benefits of adoption of IT in agricultural practices}

Emerging technologies revolutionize the ways people live, interact with each other and do business (Schwab, 2017). Digitization has heavily affected agriculture as well. According to Stratigea (2009), Information and Communication Technologies (ICTs) contribute real-time systems that enable effective collaboration making the interaction and communication process easier between relevant stakeholders like policy makers, decision makers, farmers, researchers. In addition, the development of technology-driven agriculture and adoption of precision agriculture technologies (PAT) managing the in-field heterogeneity, gives the opportunity to the companies to design the agricultural value chain in detail (El Bilali \& Allahyari, 2018; Stafford, 2000) and to face the challenges that agriculture and food industry meet. Consumers want high-quality food at low prices - with the utmost respect for animal and environmental protection. To achieve this, it is necessary to improve production and management processes (Banhazi et al., 2012). With technically supported methods for the individualization of field management and livestock farming plants and animals in an agricultural enterprise receive exactly the treatment they need (Berckmans, 2014). Specifically, there occurs the targeted management of agricultural land - using intelligent electronics. Examples include sensor-assisted soil assessment, automated animal observation on pasture or targeted control of agricultural machinery. Modern methods of differentiated management allow a site-specific work within a parcel (Morimoto \& Wadamori, 2018; Jordan et al., 2016).

Technology-driven agriculture can provide environmental and economic benefits through the reduction or targeted introduction of agricultural inputs including water, pesticides and nutrients (van Evert et al., 2017). So, accurate applications of nutrients can bring significant environmental and economic benefits. The goal is to apply only the nutrients that the plants need and can use (Zavala-Yoe et al., 2017). In addition, it may be necessary to manage the application in environmentally sensitive areas (Luck et al., 2010). Application rates will vary in the field depending on soil type, fertility levels and environmental sensitivity. Some areas may require reduced rates because of their environmental sensitivity ( $\mathrm{Fu}$ et al., 2018). Specific pesticide applications can provide economic and environmental benefits. For instance, the use of light bar guidance systems that are cheap and fast, leads environmental benefits for pesticide applications (Balafoutis et al., 2017). These affordable lights bar guidance systems provide a simple method of getting equipment through a field to avoid overlap when pesticides are sprayed.

Sensors, drones and robots make it possible to collect exactly the information that is required for a tailor-made farm (Elijah et al., 2018). With the help of sensors and satellite control, different soil characteristics and yield capabilities within the field can be electronically determined in a so-called field record file and individually responded to in real time (Faccilongo et al., 2016; Zhao \& Yang, 2018). Seed, fertilizers and pesticides can be used in a targeted and reduced way and fuel consumption can be reduced thanks to the satellite-controlled safe tracking of agricultural machinery and intelligent sensors (Zhang et al., 2017). Sensors also determine wind conditions and solar radiation in order to automatically control the irrigation system based on the measured values or to trigger the order for a required fertilizer (Yan, 2017).

Aerial images of drones provide valuable information about the field, such as soil quality, accompanying flora and diseases on plants (Smith \& Chan, 2017). The data are available at short notice and appropriate measures can be taken (Parra et al., 2017). An agricultural company can measure its land, calculate the density of cultivation and control the growth and development of its plants and animals. The drones give the farmer an extra pair of eyes - much like satellites that monitor fields and pastures, and control agricultural machines with GPS signals (Fernandez, 2016).

Farming data play an outstanding role as its appropriate use can improve the production process and logistics, and at the same time sustainability, climate change adaptation and mitigation (Kamilaris et al., 2017). However, the benefits of a data-driven agriculture can only be used if the necessary measures can be derived from the data. Surely, the data gets vast (Yao et 
al., 2018) and farmers are not always able to analyze very large amounts of data without significant assistance. It is more likely to happen if the support is conditional on the adoption of BDA (Big Data Analytics) tools like machine learning or data mining (Ghosh, 2016; Van \& Ryan, 2018; Rajeswari et al., 2018). Then, FMIS (Farm Management Information System) and DSS (Decision Support Systems) can be the basis for successful information exploitation. After having all necessary information, using FMIS and DSS, it is possible to analyze and make them available in a useful form to the agricultural entrepreneur to improve the decision-making process and the farming system as a whole (Zaza et al., 2018; Paraforos et al., 2016). This means that farmers will be offered with choices that solve the problems regarding to production process and environmental impact (Fig. 2).

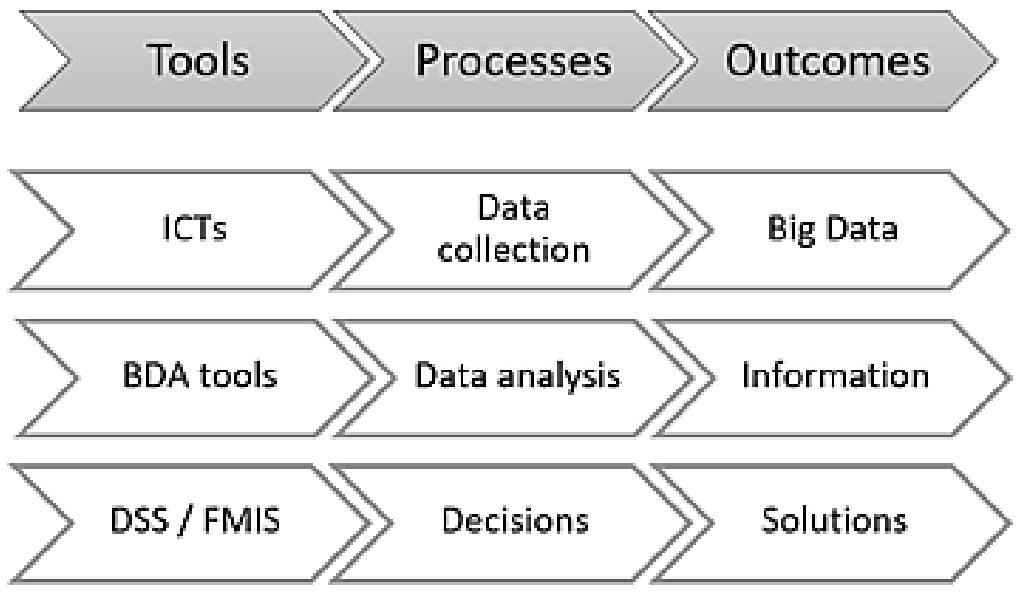

Fig 2. Data towards innovative solutions. Source: our processing

With the other words, ICTs provide farmers with enormous amount of data. The skills to analyze them exceed the human brain capacity. So, there is a need of specific tools for BDA that transform this enormous data into useful information. Then, DSS can provide particular choices for individual cases taking into account as productivity as environmental impact.

On the other hand, adoption of emerging technologies is quite costly and requires high initial investments. Not all smallholders are able to pay such a high price in machineries (Yigezu et al., 2018). Therefore, there is a need of the investments aimed at the modernization and digitization of the companies and the processing of agricultural products. It will increase commercial value of the products and support the improvement of the supply chains, aggregating and strengthening the production phase, increasing the competitiveness of the producers (Bazzani \& Canavari, 2013; Carbone, 2017). Indeed, many Italian regions use the measures useful for the development of technological and sustainable innovations for the improvement of products and production processes and for the promotion of food products (Frascarelli, 2012; La Sala et al., 2017a; La Sala et al., 2017b).

\section{A model of successful ecosystem for agriculture sector}

The data are becoming the capital of agricultural suppliers. They help to optimize offers and develop tailor-made products and services (Tripathy et al., 2014). By sharing the data, knowledge and experience as well, additionally with targeted policies and relevant investment in the field, successful and sustainable agriculture sector will be developed (Rickard, 2015; Barakabitze et al., 2015). So, for successful agriculture, it is essential that the relationship among actors be maintained, as agriculture is complex, individual processes depend on each other and a good return is associated with perfectly organized and efficient work steps (Tesdell, 2016; de Olde et al., 2017; Baker et al., 2016). Therefore, the future-oriented aids, described in the previous sections, require a legal basis and relevant investment too (Barnes et al., 2019; Koutsos \& Menexes, 2019; Yigezu et al., 2018). So, a farm success is seen at the center of a triangle between technology, collaboration and knowledge, strengthened by regulations and 
funds (Fig. 3). Here, the government has a remarkable potential to foster innovations by making targeted policies and investments. On the other hand, government can play an important role to promote the technological advances and increase awareness of its importance in the country as a whole (FuJun et al., 2018; Seeman et al., 2007). In this way it is more prospective that more bodies will be involved in the process of sustainable development and will make investments for financial or environmental interests.

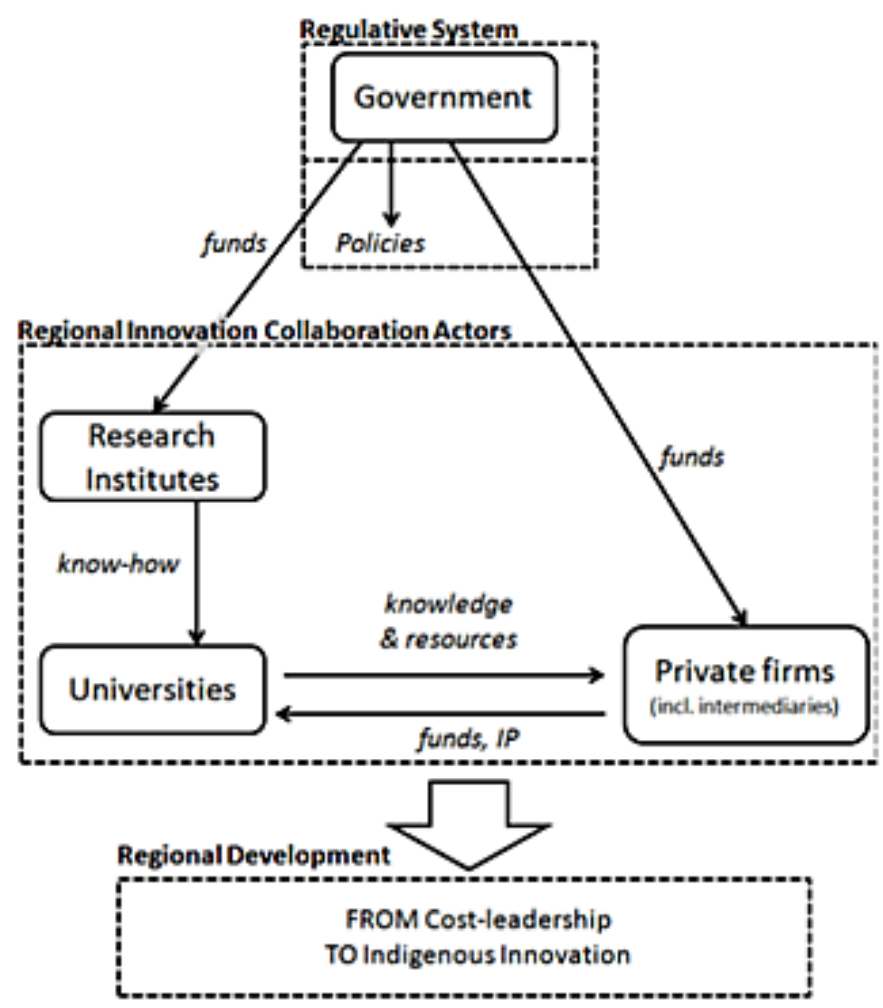

Fig 3. Conceptual model of regional innovation collaborations. Source: Zhao et al., 2014

Regarding these necessities, Zhao et al. (2014) offer the model of innovation collaborations (Fig. 3). The model shows collaboration scheme where government regulates the policies and makes investment in research and private firms. These two are exchanging knowledge and funds. At the end, the system results in high innovative outputs instead of just cost leadership position.

Based on the idea of this model, we have reconstructed the "successful ecosystem for agriculture sector" model (Fig. 4), giving remarkable importance to the adoption of information technologies. Similarly, to the model of Zhao, we describe the ecosystem where government plays a crucial role by creating targeted policies, funding research activities, producer companies of information technologies and their adopter farms, so, making contribution in the development of emerging technologies. Research institutes and universities, on the other hand, provide knowledge that together with technologies and thanks to the collaboration of the actors and information/knowledge sharing, is a basis of farmers' success.

In addition to Zhao's model, we consider that promotion of emerging technologies, their adoption in agricultural practices and their role regarding sustainability issues can play remarkable role to increase awareness in profitability of their adoption in the sense of environmental and financial benefits (Mah \& Yeo, 2014; Dong, 2007). This may cause increased interest of farms and private companies as investors. 


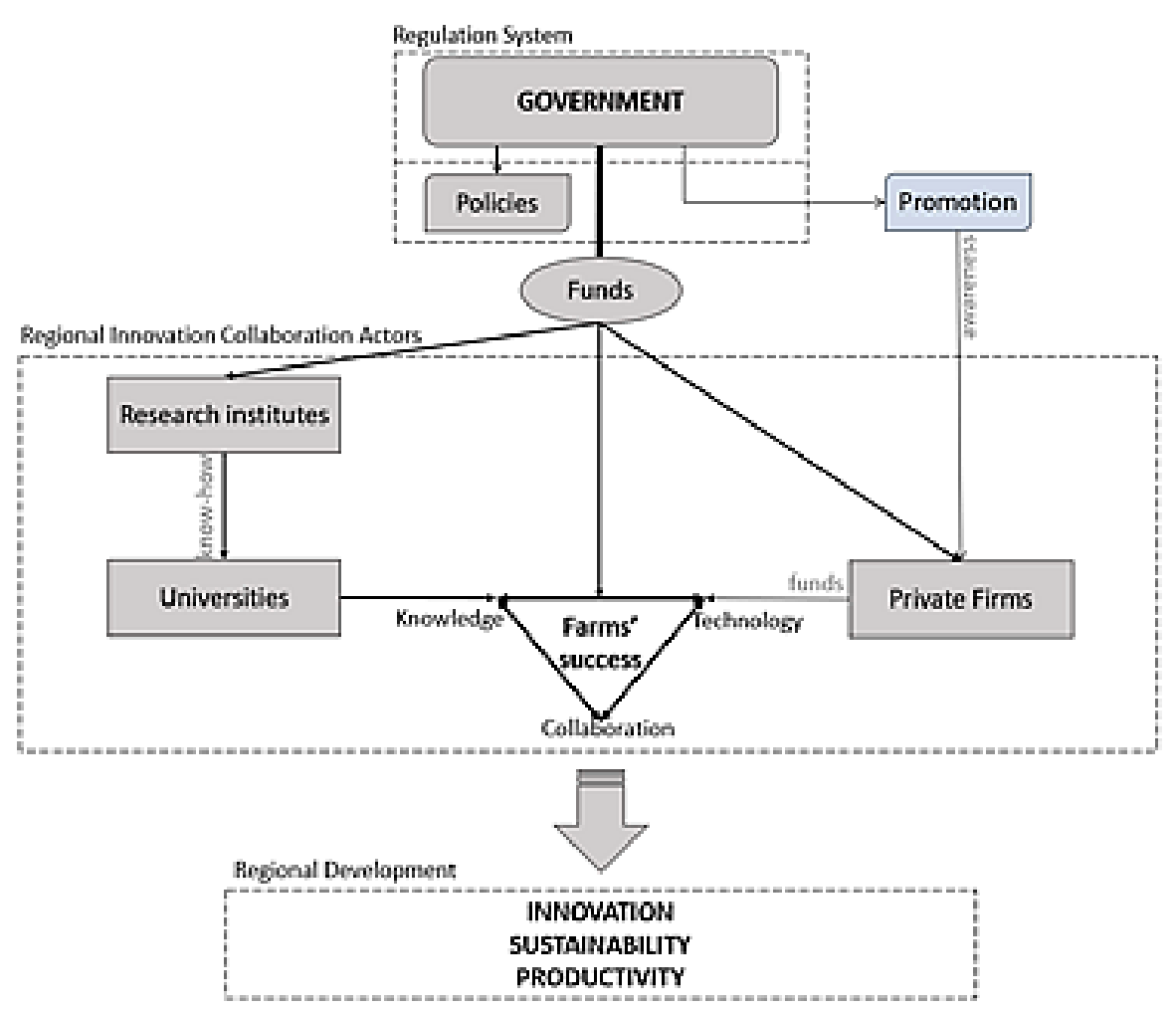

Fig 4. Model of successful ecosystem for agriculture sector. Source: our processing

The ecosystem that functions as described in the model, if all actors and stakeholders collaborate with each other, will result high innovation, productivity and sustainability in agricultural processes. Thus, instead of limiting with cost-leadership strategy, the farms will have an opportunity to move the focus towards indigenous innovations as it happened in the case of Zhao et al. (2014).

\section{Results and discussion}

Nowadays, the main trend that can be outlined is the increasing demand for safe and quality products allied to the environmental impact of agri-food sector, which is linked to the performance of supply chains. This trend leads to search for trust-based and alternative food networks and to identify visionary leadership with more effective collaborations between key stakeholders in both the public and the private sectors (Blom-Zandstra et al., 2016) aimed at improving production process and contemporary at promoting sustainable impact (Bazzani \& Canavari, 2013). Indeed, strengthening of the partnership enhances stakeholders providing them the contractual force and the market power (Cantarelli, 2016; Alho, 2015), which resulted in the ability to meet consumers' needs (Bojar \& Drelichowski, 2008). Literally, strong network of key actors of agri-food supply and close collaborative relationships between public or private players, provide the industry with the ability to match demand and supply in an effective way. Additionally, stakeholders reach higher performance and greater results when acting collaboratively rather than in isolation (Simatupang \& Sridharan, 2002; Sacchi et al., 2018).

It is more likely to achieve afore-mentioned result if trust-based collaborations are promoted by regulations and Local Development Plans (LDPs). Governments can direct all the solutions to the specific circumstances of the local areas and to ensure that the necessity of territory and sector will be met (Kotu et al., 2017). Furthermore, governments play significant role to promote new trends and to encourage the training of labour force regarding the requirements of modern market. Social capital, in turn, is a crucial factor for economic development (Fischer, 2013; Casieri et al., 2010; Simatupang \& Sridharan, 2002).

Moreover, in order to be able to keep agricultural operations up to date and as effective as possible, farmers in both upstream and downstream sectors require data regarding agricultural 
issues, latest market developments and diverse farming methods (Kamilaris et al., 2017). Knowledge became the key strategic element for competitiveness. In the era of information economy, the Information and Communication Technologies (ICTs) combined with data management are powerful tools (Ghosh, 2016; Van \& Ryan, 2018). They gain information from the huge amount of data generated by the Precision Agriculture Technologies (PAT), such as environmental sensors, Unmanned Aerial Vehicles (UAVs), satellite images, etc. and analyse it (Rajeswari et al., 2018). The agricultural working environment has recently been heavily affected by technological advancements, such as the use of electronic systems and data transmission. More precisely, being able to retrieve satellite imagery would allow stakeholders to monitor the territory and to plan how to use the landscape in order to avoid undesired results (FAO, 2015). Because climate change heavily influences agriculture and country operations, easily accessible digital tools get monitor forest cover, land use patterns and data changes over time, have growing potential for wide use. Consequently, the PATs give the opportunity to gain vast amount of data about agricultural practices, analyse them, share between stakeholders and make strong network of the key actors in agriculture sector. However, it is not easy for all smallholders to adopt to emerging technologies, since they are quite costly and requires high initial investments (Yigezu et al., 2018). Therefore, the financial contribution of public and private sectors become crucially important.

\section{Conclusion}

The advances for sustainable agricultural production and overall process efficiency, largely depend on the advancement of agricultural research and on the implementation of effective strategies as well as on relevant policies that would be used in firms through innovation and technology transfer. Innovations such as the Internet of Things, Cloud Computing and Big Data are revolutionizing agriculture. Having access to supporting technology and establishing effective trust-based communication between farmers, researchers and policy makers are crucial for the overall process efficiency (Tesdell, 2016). Collaboration is the main driving force for economic growth in the last century (Weaver, 2008) as it enhances innovation capacities of the network members (Kühne et al., 2015). These circumstances underline a need for the effective agricultural policies that would lead the technological innovation and collaboration and information/knowledge exchange between key stakeholders. The agricultural policies that include collaborative activities between public and private players, farmers, suppliers, consumers and researches, will encourage the progress of agricultural processes. Therefore, a much more effective result that could be created is all three participating parties working on a unanimous solution for an effective policy that would boost the agricultural productivity (Baker et al., 2016). Thus, the solution would be used towards improving the challenges with increased food production, effects of climate change and environmental factors. It needs to be emphasized that the increase in investments in agricultural research and interest in development of ICT, helps ICT and data management to progress in a refreshing way.

Based on the model proposed in the paper and consequently on the literature reviewed, authors elaborate several recommendations for the government:

- It would be very helpful for the industry if stakeholders had access to the necessary information, for instance, by establishing open data sources containing detailed information about agricultural practices;

- The government can increase the general awareness of the population about the benefits of IT and promote it in this way;

- The government can support the adoption of IT by financial aid;

- Establishing different grants for applicable research projects would have strong impact on the industry: it would increase the scientific knowledge; the projects may contain training activities for human capital; and the results of the projects will be useful for the industry. 
[1] Alho, E. (2015). Farmers' self-reported value of cooperative membership: evidence from heterogeneous business and organization structures. Agricultural and Food Economics 3(23). DOI: 10.1186/s40100-015-0041-6.

[2] Baker, T., Caracciolo, C., Doroszenko, A. \& Suominen, O. (2016). GACS core: Creation of a global agricultural concept scheme. In Garoufallou, E., Subirats Coll, I., Stellato, A. \& Greenberg, J., eds., Metadata and Semantics Research (pp. 311-316). Cham: Springer. DOI: 10.1007/978-3-319-49157-8_27.

[3] Balafoutis, A., Beck, B., Fountas, S., Vangeyte, J., van der Wal, T., Soto, I., GómezBarbero, M., Barnes, A. \& Eory, V. (2017). Precision Agriculture Technologies Positively Contributing to GHG Emissions Mitigation, Farm Productivity and Economics. Sustainability 9(1339), 1-28. DOI: 10.3390/su9081339.

[4] Banhazi, T., Babinszky, L., Halas, V. \& Tscharke, T. (2012). Precision livestock farming: Precision feeding technologies and sustainable livestock production. International Journal of Agricultural and Biological Engineering 5(4), 54-61. DOI: 10.3965/j.jjabe.20120504.006.

[5] Barakabitze, A., Kitindi, E., Sanga, C., Shabani, A., Philipo, J. \& Kibirige, G. (2015). New technologies for disseminating and communicating agriculture knowledge and information: Challenges for agricultural research institutes in Tanzania. Electronic Journal of Information Systems in Developing Countries 70 (1), 1-22. DOI. 10.1002/j.1681-4835.2015.tb00502.x.

[6] Barati, A. A., Kalantari, K., Nazari, M. R. \& Asadi, A. (2017). A hybrid method (ANP-SWOT) to formulate and choose strategic alternatives for development of rural cooperatives in Iran. Journal of Agricultural Science and Technology 19(4), 757-769.

[7] Barnes, A., De Soto, I., Eory, V., Beck, B., Balafoutis, A., Sánchez, B., Vanguyte, J., Fountas, S., van der Wal, T. \& Gómez-Barbero, M. (2019). Influencing factors and incentives on the intention to adopt precision agricultural technologies within arable farming systems. Environmental Science and Policy 93, 66-74. DOI: 10.1016/j.envsci.2018.12.014.

[8] Bazzani, C. \& Canavari, M. (2013). Alternative agri-food networks and short food supply chains: A review of the literature. Economia Agro-Alimentare 15(2), 11-34. DOI: 10.3280/ECAG2013-002002.

[9] Berckmans, D. (2014). Precision livestock farming technologies for welfare management in intensive livestock systems. Revue scientifique et technique 33(1), 189-196. DOI: 10.20506/rst.33.1.2273.

[10] Blom-Zandstra, M., Korevaar, H., Stuiver, M. \& Groot, A. (2016). Critical success factors for governing farmer-managed public goods in rural areas in the Netherlands. International Journal of Agricultural Sustainability 14(1), 45-64. DOI: 10.1080/14735903.2015.1024972.

[11] Bojar, W. L. \& Drelichowski, L. (2008). Analysis of tendencies in agribusiness networking coopetition in Poland and in the partner countries. Journal of Central European Agriculture 9(3), 445-456.

[12] Cantarelli, F. (2016). Le sfide per uno sviluppo sostenibile del sistema agroalimentare italiano e non solo. Economia Agro-Alimentare 2, 229-238. DOI: 10.3280/ECAG2016002007.

[13] Carbone, A. (2017). Food supply chains: coordination governance and other shaping forces. Agricultural and Food Economics 5(7). DOI: 10.1186/s40100-017-0077-x.

[14] Carrillo, F. J., Yigitcanlar, T., Garcia, B. \& Lonnqvist, A. (2014). Knowledge and the city: Concepts, applications and trends of knowledge-based urban development. New York: Routledge.

[15] Casieri, A., Nazzaro, C. \& Roselli, L. (2010). Trust building and social capital as development policy tools in rural areas. An empirical analysis: The case of the LAG CDNISAT. New Medit 9(1), 24-30. 
[16] Chmieliński, P., Faccilongo, N., Fiore, M., La Sala, P. (2018). Design and implementation of the Local Development Strategy: a case study of Polish and Italian Local Action Groups in 2007-2013. Studies in Agricultural Economics 120, 25-31. DOI: 10.7896/j.1726.

[17] Contò, F., Fiore, M., La Sala, P. (2012). The Metadistrict as the Territorial Strategy: From Set Theory and a Matrix Organization Model Hypothesis. International Journal on Food System Dynamics 3(1), 82-94. DOI: 10.18461/ijfsd.v3i1.318.

[18] Contò, F., Santini, C., La Sala, P., Fiore, M. (2016). Reducing information gap and Increasing market orientation in the agribusiness sector: some evidences from Apulia Region. Recent Patents on Food, Nutrition \& Agriculture 8(1), 48-54. DOI: $10.2174 / 221279840801160304144309$.

[19] de Olde, E., Carsjens, G. \& Eilers, C. (2017). The role of collaborations in the development and implementation of sustainable livestock concepts in The Netherlands. International $\begin{array}{llll}\text { Journal of Agricultural } & \text { Sustainability 153-168. }\end{array}$ DOI: 10.1080/14735903.2016.1193423.

[20] Dong, S. (2007). How to promote the commercialization of emerging technology: The challenge and the role of chinese government. In Advances in Management of Technology - Proceedings of the International Conference on Management of Technology (pp. 498-503). Taiyuan.University of Technology.

[21] El Bilali, H. \& Allahyari, M. (2018). Transition towards sustainability in agriculture and food systems: Role of information and communication technologies. Information Processing in Agriculture 5(4), 456-464. DOI: 10.1016/j.inpa.2018.06.006.

[22] Elijah, O., Rahman, T., Orikumhi, I., Leow, C. \& Hindia, M. (2018). An Overview of Internet of Things (IOT) and Data Analytics in Agriculture: Benefits and Challenges. IEEE Internet of Things Journal 5(5), 3758-3773. DOI: 10.1109/jiot.2018.2844296.

[23] Faccilongo, N., Contò, F., Dicceca, R., Zaza, C. \& La Sala, P. (2016). RFID sensor for agrifood supply chain management and control. International Journal of Sustainable Agricultural Management and Informatics 2(2-4), 206-221. DOI: 10.1504/ijsami.2016.10002896.

[24] Fernandez, P. (2016). Through the looking glass: envisioning new library technologies people tracking technologies. Library Hi Tech News 36(2). 1-5. DOI: 10.1108/lhtn-07-20160033.

[25] Fischer, C. (2013). Trust and communication in European agri-food chains. Supply Chain Management: 18(2), 208-218, DOI: 10.1108/13598541311318836.

[26] Frascarelli A. (2012), Migliorare il funzionamento della filiera alimentare: una valutazione degli strumenti per la pac dopo il 2013. Economia Agro-Alimentare 1, 319-340. DOI: 10.3280/ECAG2012-001015.

[27] Fu, W., Gao, N., An, X. \& Zhang, J. (2018). Study on Precision Application Rate Technology for maize no-tillage planter in North China Plain. IFAC-Papers OnLine 51(17), 412-417. DOI: 10.1016/j.ifacol.2018.08.186.

[28] FuJun, W., Zhou, Y., YingGang, O., XiangJun, Z. \& JieLi, D. (2018). "Government-industryuniversity-research-promotion" collaborative innovation mechanism construction to promote the development of agricultural machinery technology. IFAC-PapersOnLine 51(17), 552559. DOI: 10.1016/j.ifacol.2018.08.147.

[29] Ghosh, D. (2016). Big Data in Logistics and Supply Chain management - A rethinking step. In 2015 International Symposium on Advanced Computing and Communication, ISACC (pp. 168-173). Piscataway: IEEE. DOI: 10.1109/isacc.2015.7377336.

[30] Huttunen, S. (2012). Wood energy production, sustainable farming livelihood and multifunctionality in Finland. Journal of Rural Studies 28(4), 549-558. DOI: 10.1016/j.jrurstud.2012.06.003. 
[31] Jordan, R., Eudoxie, G., Maharaj, K., Belfon, R. \& Bernard, M. (2016). AgriMaps: Improving site-specific land management through mobile maps. Computers and Electronics in Agriculture 123, 292-296. DOI: 10.1016/j.compag.2016.02.009.

[32] Kamilaris, A., Kartakoullis, A. \& Prenafeta-Boldú, F. (2017). A review on the practice of big data analysis in agriculture. Computers and Electronics in Agriculture 143, 23-37. DOI: 10.1016/j.compag.2017.09.037.

[33] Keeney, D. (1990). Sustainable Agriculture: Definition and Concepts. Journal of Production Agriculture 3(3), 281. DOI: 10.2134/jpa1990.0281.

[34] Kotu, B. H., Alene, A., Manyong, V., Hoeschle-Zeledon, I. \& Larbi, A. (2017). Adoption and impacts of sustainable intensification practices in Ghana. International Journal of Agricultural Sustainability 15(5), 539-554. DOI: 10.1080/14735903.2017.1369619.

[35] Koutsos, T. \& Menexes, G. (2019). Economic, agronomic, and environmental benefits from the adoption of precision agriculture technologies: A systematic review. International Journal of Agricultural and Environmental Information Systems 10(1), 40-56. DOI: 10.4018/ijaeis.2019010103.

[36] Krantz, L. (2001). The Sustainable Livelihood Approach to Poverty Reduction. Stockholm: SIDA.

[37] Kühne, B., Gellynck, X. \& Weaver, R. D. (2015). Enhancing Innovation Capacity Through Vertical, Horizontal, and Third-Party Networks for Traditional Foods. Agribusiness 31 (3), 294-313. DOI: 10.1002/agr.21408.

[38] La Sala, P., Silvestri, R., Lamonaca, E. \& Faccilongo, N. (2017a). Le capacità relazionali quali risorse critiche per la creazione di valore nella filiera vitivinicola lucana. Economia Agro-Alimentare 3, 383-398. DOI: 10.3280/ECAG2017-003005.

[39] La Sala, P., Silvestri, R. \& Contò, F. (2017b). Differentiation strategies for the wine and nursery sector: empirical evidence from an Italy region. Agricultural and Food Economics (AFE) 5(23). DOI: 10.1186/s40100-017-0091-z.

[40] Luck, J., Pitla, S., Shearer, S., Mueller, T., Dillon, C., Fulton, J. \& Higgins, S. (2010). Potential for pesticide and nutrient savings via map-based automatic boom section control of spray nozzles. Computers and Electronics in Agriculture 70(1), 19-26. DOI: 10.1016/j.compag.2009.08.003.

[41] Luostarinen, M. (1998). Integrated environmental research and networking of economy and information in rural areas of Finland. Agricultural and Food Science in Finland 7(2), 315328. DOI: $10.23986 /$ afsci.72856.

[42] Mah, J. S. \& Yeo, M. (2014). The role of the government in R\&D promotion and the development of technology-intensive industries in China. China Report 50(2), 91-107. DOI: $10.1177 / 0009445514523644$.

[43] Miller, N., Griffin, T., Ciampitti, I. \& Sharda, A. (2018). Farm adoption of embodied knowledge and information intensive precision agriculture technology bundles. Precision Agriculture 20(2), 348-361. DOI: 10.1007/s11119-018-9611-4.

[44] Morimoto, E. \& Wadamori, T. (2018). Data evaluation for tractor operation based on GNSS and multiple sensors. In 2018 ASABE Annual International Meeting (No. 1800999). St. Joseph, Ml: American Society of Agricultural and Biological Engineers. DOI: 10.13031/aim.201800999.

[45] Nazzaro, C. \& Marotta, G. (2016). The Common Agricultural Policy 2014-2020: scenarios for the European agricultural and rural systems. Agricultural and Food Economics 4(16), 15. DOI: 10.1186/s40100-016-0060-y.

[46] Odara, S., Khan, Z. \& Ustun, T. S. (2015). Integration of precision agriculture and SmartGrid technologies for sustainable development. Proceedings - 2015 IEEE 
International Conference on Technological Innovations in ICT for Agriculture and Rural Development TIAR 2015, 84-89. DOI: 10.1109/TIAR.2015.7358536.

[47] Paraforos, D., Vassiliadis, V., Kortenbruck, D., Stamkopoulos, K., Ziogas, V., Sapounas, A. \& Griepentrog, H. (2016). A Farm Management Information System Using Future Internet Technologies. IFAC-PapersOnLine 49(16), 324-329. DOI: 10.1016/j.ifacol.2016.10.060.

[48] Parra, H., Gomes, J. \& Shebl, H. (2017). Integrated workflow for building 3D digital outcrop models using unmanned aerial vehicles - Drones: Field case Thamama Group, Wadih Rahbah, UAE. In Abu Dhabi International Petroleum Exhibition \& Conference, 13-16 November, Abu Dhabi, UAE. Abu Dhabi: Society of Petroleum Engineers. DOI: 10.2118/188477-ms.

[49] Rajeswari, S., Suthendran, K. \& Rajakumar, K. (2018). A smart agricultural model by integrating loT, mobile and cloud-based big data analytics. Proceedings of 2017 International Conference on Intelligent Computing and Control (pp. 1-5), Piscataway: IEEE. DOI: 10.1109/i2c2.2017.8321902.

[50] Rickard, S. (2015). Food security and climate change: The role of sustainable intensification, the importance of scale and the CAP. EuroChoices 14(1), 48-53. DOI: $10.1111 / 1746-692 x .12082$.

[51] Rossi, V., Caffi, T. \& Salinari, F. (2012). Helping farmers face the increasing complexity of decision-making for crop protection. Phytopathologia Mediterranea 51(3), 457-479. DOI: $10.14601 /$ Phytopathol_Mediterr-11038.

[52] Sacchi, G., Cei, L., Stefani, G., Lombardi, G. V., Rocchi, B., Belletti, G., Padel, S., Sellars, A., Gagliardi, E., Nocella, G., Cardey, S., Mikkola, M., Ala-Karvia, U., Macken-Walsh, A., McIntyre, B., Hyland, J., Henchion, M., Bocci, R., Bussi, B., De Santis, G., Rodriguez, Y., Hurtado, I., de Kochko, P., Riviere, P., Carrascosa-García, M., Martínez, I., Pearce, B., Lampkin, N., Vindras, C., Rey, F., Chable, V., Cormery, A. \& Vasvari, G. (2018). A multiactor literature review on alternative and sustainable food systems for the promotion of cereal biodiversity. Agriculture (Switzerland) 8(11), 173. DOI: 10.3390/agriculture8110173.

[53] Schwab, K. (2017). The Fourth Industrial Revolution. New York: Currency.

[54] Schneider, S., Salvate, N. \& Cassol, A. (2016). Nested markets, food networks, and new pathways for rural development in Brazil. Agriculture (Switzerland) 6(4), 61. DOI: 10.3390/agriculture6040061.

[55] Seeman, E. D., O'Hara, M. T., Holloway, J. \& Forst, A. (2007). The impact of government intervention on technology adoption and diffusion: The example of wireless location technology. Electronic Government 4(1), 1-19. DOI: 10.1504/EG.2007.012176.

[56] Smith, W. \& Chan, P. (2017). Impact of drones on precision agriculture. In 7th International Workshop on Computer Science and Engineering, WCSE 2017 (pp. 1235-1239). Beijing: China Agricultural University.

[57] Stafford, J. V. (2000). Implementing Precision Agriculture in the 21st Century. Journal of Agricultural. Engineering Research 76(3), 267-275. DOI: 10.1006/jaer.2000.0577.

[58] Steiner, B. E. (2017). A phenomenon-driven approach to the study of value creation and organizational design issues in agri-business value chains. Economia Agro-Alimentare 1, 89-118. DOI: 10.3280/ECAG2017-001005.

[59] Stratigea, A. (2009). Participatory planning and sustainable local development-A methodological approach; paper presented at the 2nd National Conference of Urban and Regional Planning and Regional Development, Vol, 24 (Proceedings 43-51). University Publishing of Thessaly.

[60] Teng, W., De Jeu, R., Doraiswamy, P., Kempler, S., Mladenova, I. \& Shannon, H. (2010). Improving world agricultural supply and demand estimates by integrating NASA remote sensing soil moisture data into USDA World Agricultural outlook Board decision making environment. In American Society for Photogrammetry and Remote Sensing Annual 
Conference 2010: Opportunities for Emerging Geospatial Technologies 2 (pp. 906-916). Bethesda, MD: ASPRS.

[61] Tenzin, S., Siyang, S., Pobkrut, T. \& Kerdcharoen, T. (2017). Low cost weather station for climate-smart agriculture. In 2017 9th International Conference on Knowledge and Smart Technology: Crunching Information of Everything, KST 2017 (pp. 172-177). Piscataway, NJ: IEEE. DOI: 10.1109/kst.2017.7886085.

[62] Tesdell, L. (2016). Innovating down on the farm: Communication networks that facilitate water quality practices. In 2016 IEEE International Professional Communication Conference (no. 7740531). Piscataway, NJ: IEEE. DOI: 10.1109/ipcc.2016.7740531.

[63] Tripathy, A., Adinarayana, J., Vijayalakshmi, K., Merchant, S., Desai, U., Ninomiya, S., Hirafuji, M. \& Kiura, T. (2014). Knowledge discovery and Leaf Spot dynamics of groundnut crop through wireless sensor network and data mining techniques. Computers and Electronics in Agriculture 107, 104-114. DOI: 10.1016/j.compag.2014.05.009.

[64] van Evert, F., Gaitán-Cremaschi, D., Fountas, S. \& Kempenaar, C. (2017). Can precision agriculture increase the profitability and sustainability of the production of potatoes and olives? Sustainability 9(10), No. 1863. DOI: 10.3390/su9101863.

[65] Van Rijmenam, M. \& Ryan, P. (2018). Blockchain: Transforming your business and our World. London: Taylor and Francis LTD.

[66] Viaggi, D., Manos, B., Chatzinikolaou, P., Bournaris, T. \& Kiomourtzi, F. (2011). A prospective analysis for the role of the CAP in rural economies and related research needs: The case of Greece. In Lee, T.H., ed., Agricultural Economics: New Research (pp. 205-226). Hauppauge, NY: Nova Science Publishers.

[67] Weaver, R. D. (2008). Collaborative pull innovation: Origins and adoption in the new economy. Agribusiness 24(3), 388-402. DOI: 10.1002/agr.20165.

[68] Yan, J. (2017). Control of sprinkler irrigation intensity based on energy self-adaptation of a wireless sensor network. Agro Food Industry Hi-Tech 28 (1), 1997-2001.

[69] Yao, Y. C., Han, Q., Yang, H. Y. \& Zhang, X. Y. (2018). The application of big data in production and environment. Journal of Physics: Conference Series 1087(3), No. 032019. DOI: 10.1088/1742-6596/1087/3/032019.

[70] Yigezu, Y. A., Mugera, A., El-Shater, T., Aw-Hassan, A., Piggin, C., Haddad, A., Khalil, Y. \& Loss, S. (2018). Enhancing adoption of agricultural technologies requiring high initial investment among smallholders. Technological Forecasting and Social Change 134, 199206. DOI: 10.1016/j.techfore.2018.06.006.

[71] Zavala-Yoe, R., Ramírez-Mendoza, R. \& García-Lara, S. (2017). A 3-SPS-1S parallel robot-based laser sensing for applications in precision agriculture. Soft Computing 21(3), 641-650. DOI: 10.1007/s00500-016-2457-7.

[72] Zaza, C., Bimonte, S., Faccilongo, N., La Sala, P., Contò, F. \& Gallo, C. (2018). A new decision-support system for the historical analysis of integrated pest management activities on olive crops based on climatic data. Computers and Electronics in Agriculture 148, $237-$ 249. DOI: 10.1016/j.compag.2018.03.015.

[73] Zecca, F., Al Am, A. \& Capocchi, E. (2014). Dai distretti alle reti d'impresa: soluzioni chiave per lo sviluppo territoriale. Rivista di Economia Agraria, 69 (2-3), 227-243. DOI: $10.13128 /$ REA-16924.

[74] Zhang, J., Wang, Y., Wang, C., Wang, R. \& Li, F. (2017). Quantifying the emergy flow of an urban complex and the ecological services of a satellite town: a case study of Zengcheng, China. Journal of Cleaner Production Suppl. 163, S267-S276. DOI: 10.1016/j.jclepro.2016.02.059. 
[75] Zhao, L. \& Yang, Z. (2018). Multi-sensor land data assimilation: Toward a robust global soil moisture and snow estimation. Remote Sensing of Environment 216, 13-27. DOI: 10.1016/j.rse.2018.06.033.

[76] Zhao, S. L, Cacciolatti, L., Lee, S. H. \& Song, W. (2014). Regional collaborations and indigenous innovation capabilities in China: A multivariate method for the analysis of regional innovation systems, Technological Forecasting and Social Change 94, 202-220. DOI: 10.1016/j.techfore.2014.09.014.

\section{Other sources}

[77] EIP-AGRI (2015). Innovative Short Food Supply Chain management. Final report 2015. Available at: https://ec.europa.eu/eip/agriculture/en/publications/eip-agri-focus-groupinnovative-short-food-supply.

[78] European Union (2012). The Common Agricultural Policy. Luxembourg: Publications Office of the European Union.

[79] FAO (2015, December 1). Google and FAO partner to make remote sensing data more efficient and accessible. Retrieved from http://www.fao.org/: http://www.fao.org/partnerships/container/news-article/en/c/356751/.

[80] FAO (2017). The future of food and agriculture. Trends and challenges. Rome: Food and Agriculture Organization of the United Nations.

[81] FAO (2018). Information and Communication Technology (ICT) in Agriculture: A Report to the G20 Agricultural Deputies. Food \& Agriculture Org.

[82] Rapsomanikis, G. (2017). G7 and Africa: Food Security, by FAO. Retrieved from ISPI Italian Institute for International Political Studies: https://www.ispionline.it/en/pubblicazione/g7-and-africa-food-security-17852.

[83] Regulation (EC) No 1305/2013 of the Commission.

[84] UN DESA (2017, June 21). United Nations - Department of Economics and Social Affairs. Retrieved from www.un.org: https://www.un.org/development/desa/en/news/population/world-population-prospects2017.html. 